\title{
Metaturbidite-hosted gold deposits, Córrego do Sítio lineament, Quadrilátero Ferrífero, Brazil
}

\author{
Depósitos auríferos em metaturbiditos, lineamento \\ Córrego do Sítio, Quadrilátero Ferrífero, Brasil
}

\author{
Jorge Geraldo Roncato Júnior ${ }^{1 *}$, Lydia Maria Lobato ${ }^{1}$, Luiz Claudio Lima ${ }^{2}$, \\ Cecília Germano Porto $^{1}$, Rosaline Cristina Figueiredo e Silva ${ }^{1}$
}

\begin{abstract}
A study of geology and rocks paragenesis has been conducted at the Córrego do Sítio auriferous lineament, containing the Cachorro Bravo, Laranjeiras and Carvoaria metaturbidite-hosted lode-gold deposits located in the Quadrilátero Ferrífero Region, Minas Gerais, Brazil. These representative deposits are described to illustrate the essentially similar general character of all the deposits of lineament as well as the wide compositional and mineralogical differences in the ore of the different deposits, where, for the Cachorro Bravo deposit, a geological mapping included two underground mine galleries. The Córrego do Sítio unit is a metamorphosed turbidite in an alternating sequence of metagraywackes and phyllites, with parallel to discordant metamafic dikes and sills. The ore zone is predominantly hosted at the stratigraphic break between metasedimentary and metamafic rocks. Four deformation events affected the mine sequence. Mineralized veins and veinlets are considered to have formed within a brittle-ductile shear-zone environment and occurred in multiple episodes. Different vein types are recognized, but the most important volumetrically is a $\mathrm{S}_{1}$-concordant type characterized by smoky and milky quartz-carbonate-sulfide \pm sulfosalts veins. Veins are dominated by quartz, but locally they are characterized by carbonate and a large variety of sulfide and sulfosalt minerals. Pyrite is the commonest associated sulfide mineral, followed by arsenopyrite and pyrrhotite. An extensive mineralogical study of polished sections has confirmed different generations of sulfide minerals. The sulfides and sulfosalt minerals are interrelated in the veins and disseminated on wall rocks. The data are consistent with a genetic models related to other Archean lode-gold deposits.
\end{abstract}

KEYWORDS: lode-gold deposits; orogenic gold; metaturbidite gold deposit
RESUMO: O estudo da geologia e paragênese do lineamento aurífero Córrego do Sítio foi conduzido, contendo os depósitos Cachorro Bravo, Laranjeiras e Carvoaria. Esses depósitos auriferos, do tipo lode, hospedados em sequência metaturbidítica ocorrem na regiáo do Quadrilátero Ferrifero, Minas Gerais, Brasil. Esses três importantes depósitos são descritos para ilustrar as características semelhantes, composição mineralógica e diferenças no tipo de minério ao longo do lineamento. Para o depósito de Cachorro Bravo, o mapeamento geológico inclui duas galerias subterrâneas. A unidade Córrego do Sítio é composta por uma sequência turbidítica com alternância de metagrauvacas e filitos, associada a diques e sills metamáficos, paralelos a discordantes. A zona de minério é predominantemente relacionada ao intervalo estratigráfico localizado entre as rochas metassedimentares e as rochas metamáficas. Quatro eventos deformacionais afetaram a sequência estratigráfica do lineamento. Veios e venulaçôes mineralizados formaram-se em vários episódios em ambiente de cisalhamento dúctil-rúptil. Diferentes tipos de veios são reconhecidos, mas a geraçáo mais importante volumetricamente é concordante à estrutura $S_{l}$. Os veios são compostos por cristais de quartzo, tanto fumê quanto leitoso, carbonato e uma grande variedade de sulfetos e sulfossais. A pirita é o sulfeto mais comum seguido por arsenopirita e pirrotita, confirmados por detalhamento mineralógico em seçôes polidas. Sulfetos e sulfossais são inter-relacionados nos veios e disseminados nas rochas encaixantes. Os dados apresentados são consistentes com modelos genéticos relacionados a outros depósitos lode-gold arqueanos.

PALAVRAS-CHAVE: depósito tipo lode-gold; ouro orogênico; depósito aurifero em metaturbidito.

\footnotetext{
${ }^{1}$ Department of Geology, Instituto de Geociências, Universidade Federal de Minas Gerais, Belo Horizonte (MG), Brazil. E-mails: roncatojr@yahoo.com.br; lobato@netuno.lcc.ufmg.br; cericita@yahoo.com.br; rosalinecris@yahoo.com.br

${ }^{2}$ Luna Gold, Mineração Aurizona S.A., Godofredo Viana (MA), Brazil. E-mail: luiz.lima@lunagold.com

*Corresponding author.

Manuscrito ID: 30198 Submetido em: 09/11/2014. Aprovado em: 21/01/2015.
} 


\section{INTRODUCTION}

The gold production in the Archean greenstone-hosted deposits of the Quadrilátero Ferrífero mining district, Brazil, is important worldwide (Ribeiro-Rodrigues 1998), with banded iron formations being the most important host to gold mineralization (Lobato et al. 2001). These authors estimated that only $4 \%$ of all the gold production of the Rio das Velhas greenstone belt are hosted in rock types other than banded iron formation (BIF) and in the hydrothermal products generically referred to as lapa seca; these $4 \%$ encompass ultramafic, mafic, volcaniclastic, and clastic rocks in general.

In the focus area, a deformed sequence of schistose sediments of the Nova Lima Group (Fig. 1), Rio das Velhas greenstone belt, crops out in a series of NE-SW regional lineaments that host gold mineralization and are known as Córrego do Sítio, Cristina and São Bento-Donana shear zones, respectively from the SE to NW (Fig. 2; Lima 2012). They contain gold deposits with resources of approximately $5.12 \mathrm{Moz}$ (Sequetto-Pereira et al. 2013). The Córrego do Sítio shear zone, now known as the Córrego do Sítio structural lineament (Lima 2012), hosts the Cachorro Bravo, Laranjeiras and Carvoaria deposits, the most important in this area.

The main rock units comprise a repetitive succession of metamorphosed carbonaceous turbiditic, graywacke-siltstone-shale and slates, which host lode-gold mineralization associated with quartz-carbonate-sulfide-sulfosalt veins (Lima 2012, Ribeiro et al. 2013). As in other Archean greenstonebelt-hosted gold deposits, those at Córrego do Sítio are at the greenschist metamorphic facies (e.g. Condie 1981, Groves et al. 1998). A series of mafic dikes and sills have been emplaced and may have had an important control for the gold mineralization and sulfide paragenesis (e.g. Canale 1999, Porto 2008, Lima 2012, Sequetto-Pereira et al. 2013, Ribeiro et al. 2013).

\section{REGIONAL GEOLOGICAL SETTING}

The Quadrilátero Ferrífero district (Fig. 1) is situated in the southern portion of the São Francisco craton (Almeida 1976) and is composed of the Archean Rio das Velhas greenstone belt (Schorscher et al. 1982), the Paleoproterozoic Minas Super Group and the Itacolomi Group. These supracrustal units are surrounded by granite-gneiss domes (Dorr 1969), which consist of poly-deformed unit. The regional basement metamorphic complex crops out in several distinct domes and has a metamorphic grade ranging from greenschist to granulite facies (Herz 1970).
The Rio das Velhas rocks comprise seven lithofacies associations (Fig. 1), according to Baltazar and Silva (1998a, 1998b), Zucchetti and Baltazar (2000), Lobato et al. (2005) and Baltazar and Zucchetti (2007), and these are, from base to top:

1. Mafic-ultramafic: lavas with minor intrusions of gabbro, anorthosite and peridotite, as well as intercalations of BIF, ferruginous chert, carbonaceous pelite, turbidites, and rare felsic volcanoclastic rocks. It corresponds to the Quebra Osso Group and Ouro Fino unit of the Nova Lima Group.

2. Volcano-chemical-sedimentary: tholeiites intercalated with BIF and ferruginous chert, as well as less finegrained clastic sedimentary rocks, such as carbonaceous turbidites and pelites, intercalated with chemical sedimentary rocks.

3. Clastic-chemical sedimentary: typified by alternating fine-grained, clastic and chemical rocks. Pelites (micaceous and chloritic schists) are intercalated with lesser BIF, subordinate chert and carbonaceous phyllites. It corresponds to the Santa Quitéria unit in the study area.

4. Volcaniclastic: with felsic and mafic rocks.

5. Re-sedimented: widely distributed in the Quadrilátero Ferrífero, it includes three different sequences of graywacke-argillite, two metamorphosed in the greenschist facies in the $\mathrm{N}$ and $\mathrm{E}$ sectors (they are composed mainly of graywackes, quartz graywackes, sandstones and siltstones, with cyclic layers and abrupt basal contacts between cycles) and one in the amphibolite facies in the south. In the E and $\mathrm{N}$ sectors, it includes the Córrego do Sítio unit outcropping in the study area.

6. Coastal: restricted to a small area, with sandstones exhibiting preserved sedimentary structures.

7. Non-marine: conglomerate-sandstone; coarse-grained sandstone, fine- to medium-grained sandstone; it includes the Casa Forte Formation of the Maquiné Group (Dorr et al. 1957).

\section{LOCAL GEOLOGY}

The term Córrego do Sítio auriferous structural lineament was initially proposed by Lima (2012) to include all gold occurrences that encompass those of the Córrego do Sítio, Cristina and São Bento-Donana shear zones (Fig. 2; Lima 2012), since they all have the same NE-SW direction and mineralization in similar lithostratigraphic hosts. In its SW extension (Fig. 2), the Córrego do Sítio lineament comprises the Carvoaria, Laranjeiras, Cachorro Bravo, Cristina, Rosalino and Grota Funda deposits. 


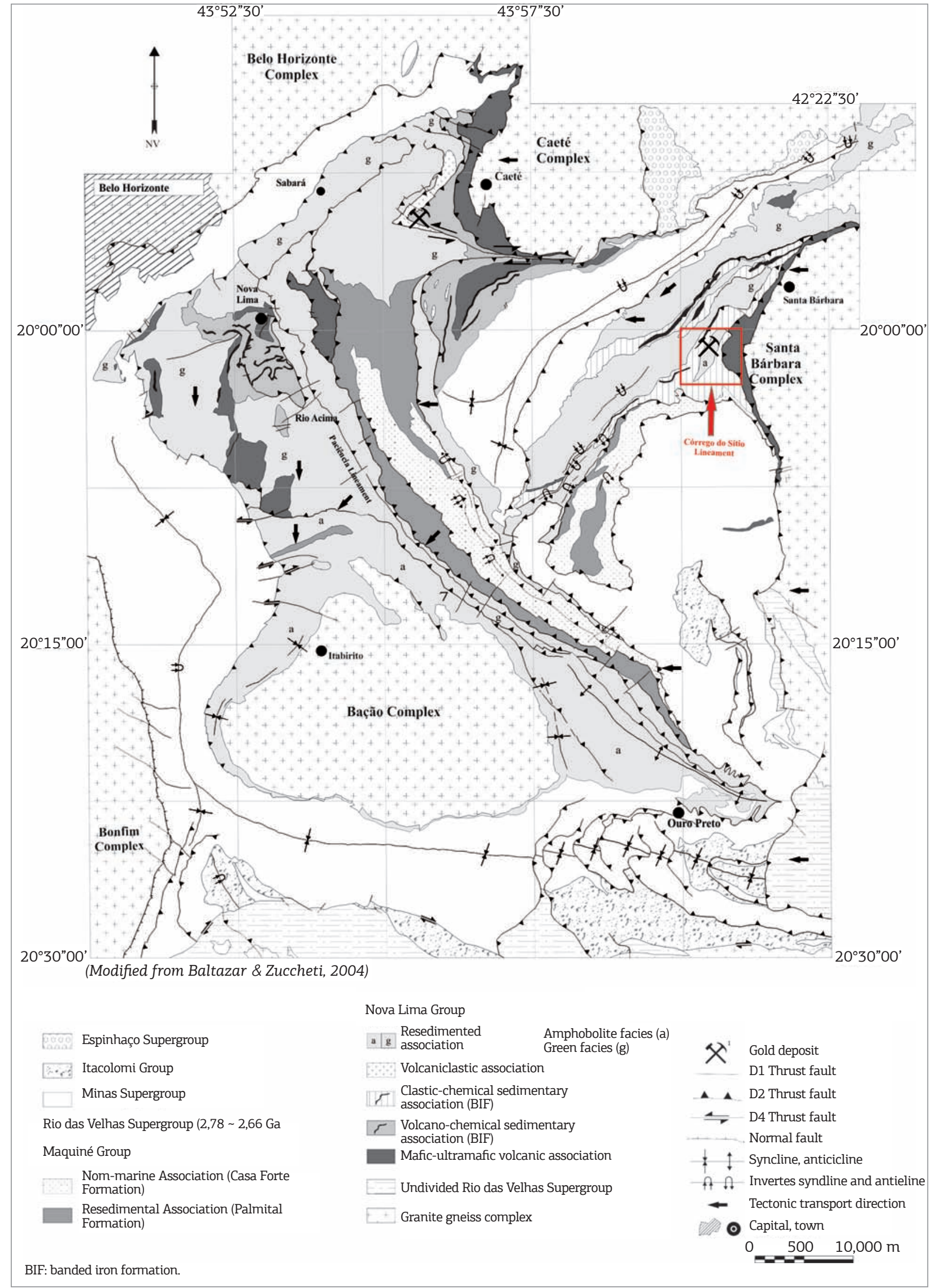

Figure 1. Geological map of the Quadrilátero Ferrífero region showing the study area in the Rio das Velhas Supergroup in detail (modified from Baltazar \& Zucchetti 2007). 


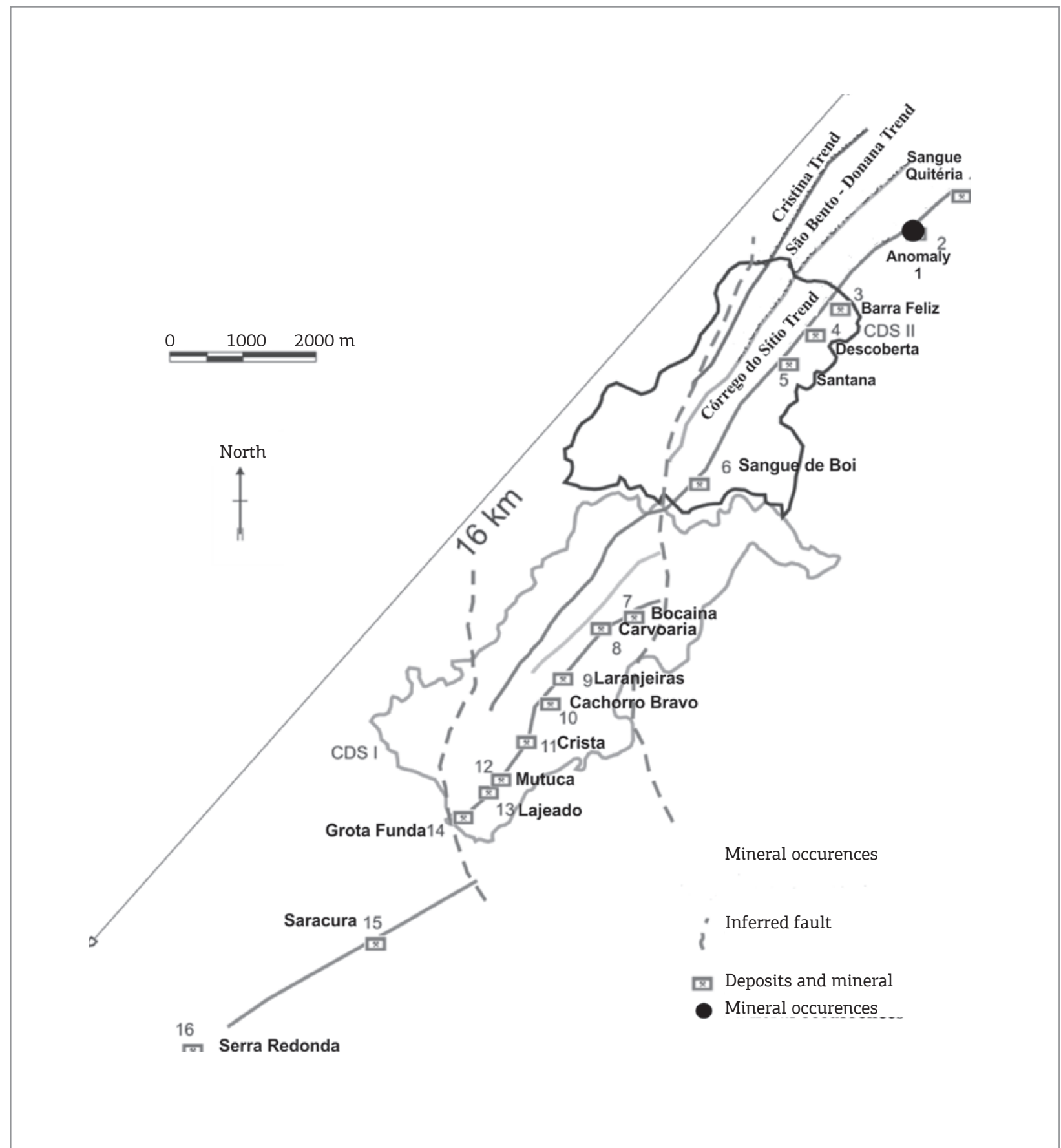

Figure 2. The NE-SW 16-km long Córrego do Sítio auriferous lineament, displaying the Cristina, São BentoDonana and Córrego do Sítio structural trends (modified from Lima 2012).

Porto (2008) and Lima (2012) consider the Córrego do Sítio lineament as a package of metasedimentary rocks consisting of alternating graywackes and phyllites in a turbidite sequence with incomplete Bouma cycles (Bouma 1983), metamorphosed to the greenschist facies. Metamafic dikes and sills are subparallel to discordant.

The Córrego do Sítio unit (Baltazar \& Silva 1998b) is widely distributed in many parts of the Quadrilátero
Ferrífero and includes sequences of graywacke and argillite. Graywackes, quartz graywackes, sandstones and siltstones display cyclic layers and abrupt basal contacts between cycles. The features of this association indicate that it was deposited by turbidity currents (Lima 2012), and this unit is considered part of the re-sedimented association.

The contacts with the metasedimentary units are abrupt, oblique and marked by the development of hydrothermal 
alteration zones containing carbonate, sericite, quartz and sulfide minerals.

From E to W, Lima (2012) mapped the Córrego do Sítio unit based on the relative proportion of the different rock types and proposed an informal stratigraphic subdivision (Fig. 3):

Lower subunit: thick carbonaceous phyllite and graywacke sequence. It contains subordinate metric-decimetric BIF layers, some of which are magnetic and intercalated with carbonaceous phyllites (Figs. 4A to 4C).

- Intermediate subunit: carbonaceous phyllite with an anastomosing schistosity hosting millimetric to metric quartz-carbonate veins and microfolded layers, transposed locally in axial plans of assymetric folds. This is where the auriferous mineralization is concentrated, with sulfide and sulfosalts in quartz-carbonate veins. The upper and lower contacts are sharp.

Upper subunit: intercalation of a thick graywacke sequence and subordinate carbonaceous phyllite in incomplete Bouma cycles. Bedding exhibits upward grain-size fining in normal and inverted sequence.

Metamafic dikes and sills have a NNE-SSW direction, dipping to the SE. Metamafic rocks with chlorite and muscovite alteration $(\mathrm{MBcl})$ are epidote-rich metagabbros (Fig. 4D, Tab. 1). Quartz-bearing, schistose chlorite-carbonate dominated metamafic rocks (MBcb) are the most hydrothermally altered; these are locally mineralized including gold (Fig. 4E, Tab. 1).

The incipiently altered metamafic rocks (MBpx) (Fig. 4F, Tab. 1) represent a fine-grained metagabbro with relict pyroxene, amphibole and plagioclase.

\section{GEOLOGY AND MINERALOGY OF THE DEPOSITS}

For the Cachorro Bravo deposit, 1:100-scale geological mapping included the outcrops exposed in a $250-\mathrm{m}$ section of the mine galleries. The host metaphyllites and metagraywackes of the 658 and 711 galleries are hydrothermally altered and deformed, showing no apparent significant geological depth variations. The mapped deposits are located exclusively in the Intermediate subunit, where the regional rocks and structural features are easily recognized and correlated (Figs. 5 and 6).

The gold-bearing ore veins take the form of narrow, mineralized lodes and elongated boudins that strike $20^{\circ}-30^{\circ}$ to the NE and dip between $60^{\circ}$ and $70^{\circ}$ to the SE. Metamafic $\mathrm{MBcl}$ dikes and sills are always located in the hanging wall; they only crop out in the 658 gallery (Fig. 5), although they occur to the west of the 711 gallery.

The galleries 658 and 711 have an N-S horizontal strike and a depth of 115 and $170 \mathrm{~m}$ below surface, respectively, with mineralized lenses that extend to $250 \mathrm{~m}$ along the length of each gallery. Each lens is about $6 \mathrm{~m}$ wide, covering an area of $1,500 \mathrm{~m}^{2}$ (Fig. 5), with the ore body plunging on average $130 / 35$. Together with graywacke lenses, carbonaceous phyllite locally dominates the mapped area along the eastern wall. In the SW portion of the 658 gallery, metamafic $\mathrm{MBcl}$ dikes and sills represent the hydrothermal alteration boundary, since these rocks are practically unaltered beyond the contact with the metasedimentary host rocks. Quartzcarbonate veins occur along the mine gallery. Fault zones are common in the carbonaceous phyllite layers. Silicification zones predominate in the southern part of the gallery.

From $\mathrm{N}$ to $\mathrm{S}$ in the mapped areas, the turbiditic sequence varies from a somewhat psammitic to more pelitic, although in general the pelitic component dominates and is mainly represented by carbonaceous phyllites; outcrops of metagraywacke are exposed on the E side (Fig. 5).

The oldest planar structure, $S_{0}$ is the compositional and gradational banding that trends to the SE and is concentrated in the phyllite layers as an upward grainsize coarsening, rarely perceptible in the metagraywacke lenses; $\mathrm{S}_{0}$ has a modal orientation of $114 / 59$ (Figs. 5D, 6D, 7A, and 7E).

The pervasive $S_{1-2}$ foliation is parallel or sub-parallel to the bedding planes. These structures are mainly present in the carbonaceous phyllite and the hydrothermally altered metamafic rocks, but are subordinate in the metagraywacke. The $S_{1-2}$ foliation is defined mainly by aligned sericite and has a strong dip to SE, with a modal orientation of $119 / 70$ (Figs. 5E, 6E, 7B, and 7F), followed by a rarely observed down-dip $\mathrm{L}_{\mathrm{m} 1-2}$ lineation with a 45/45 orientation. The dip of the foliation increases both in the $S$ direction and vertically (from the 658 to the 711 gallery) by roughly $1-2$ degrees, and regionally it is more intense in the SW quarter. Folds are well visualized when structural data from various levels are compiled. They are well defined by the main foliation $S_{1-2}$ in metasedimentary rocks.

The $S_{3}$ crenulation cleavage is an important structural element characterized by having an opposing dip to $S_{1-2}$. Similarly to $S_{1-2}$, this structure is very well marked in the carbonaceous phyllite and is subordinate in graywackes (Figs. 5F, 6F, 7C, and 7G). The $S_{3}$ crenulation cleavage data is concentrated in the $\mathrm{SE}$ quarter with orientations 280/60, 250/65, and 270/66 (Figs. 5F, 6F, and 7D).

The last structure recognized in the mapped areas is the $\mathrm{S}_{4}$ spaced fracture cleavage, with a N-NW direction and 


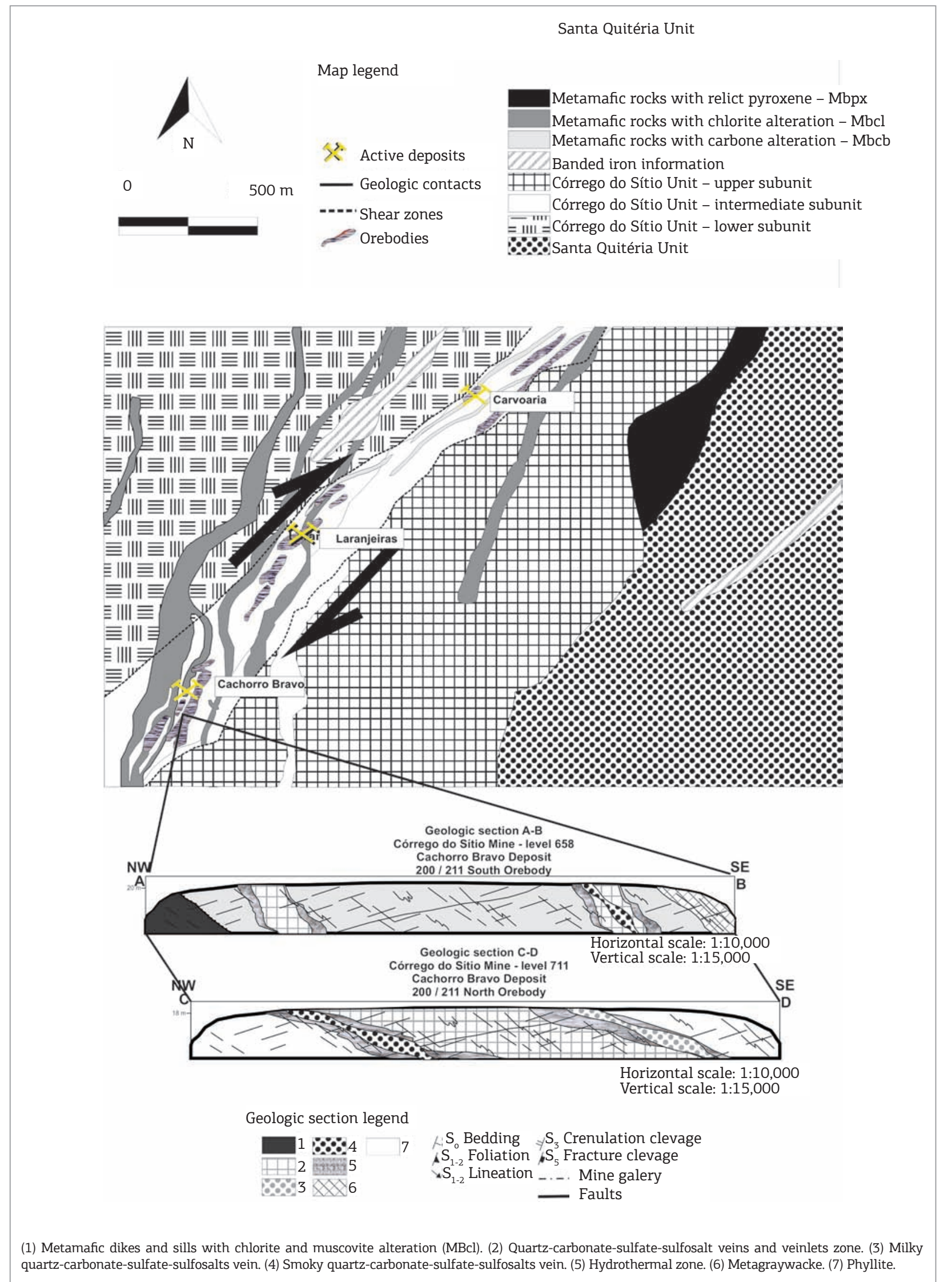

Figure 3. Geological map of the Córrego do Sítio Lineament, central portion (modified from Sequetto-Pereira et al. 2013) 

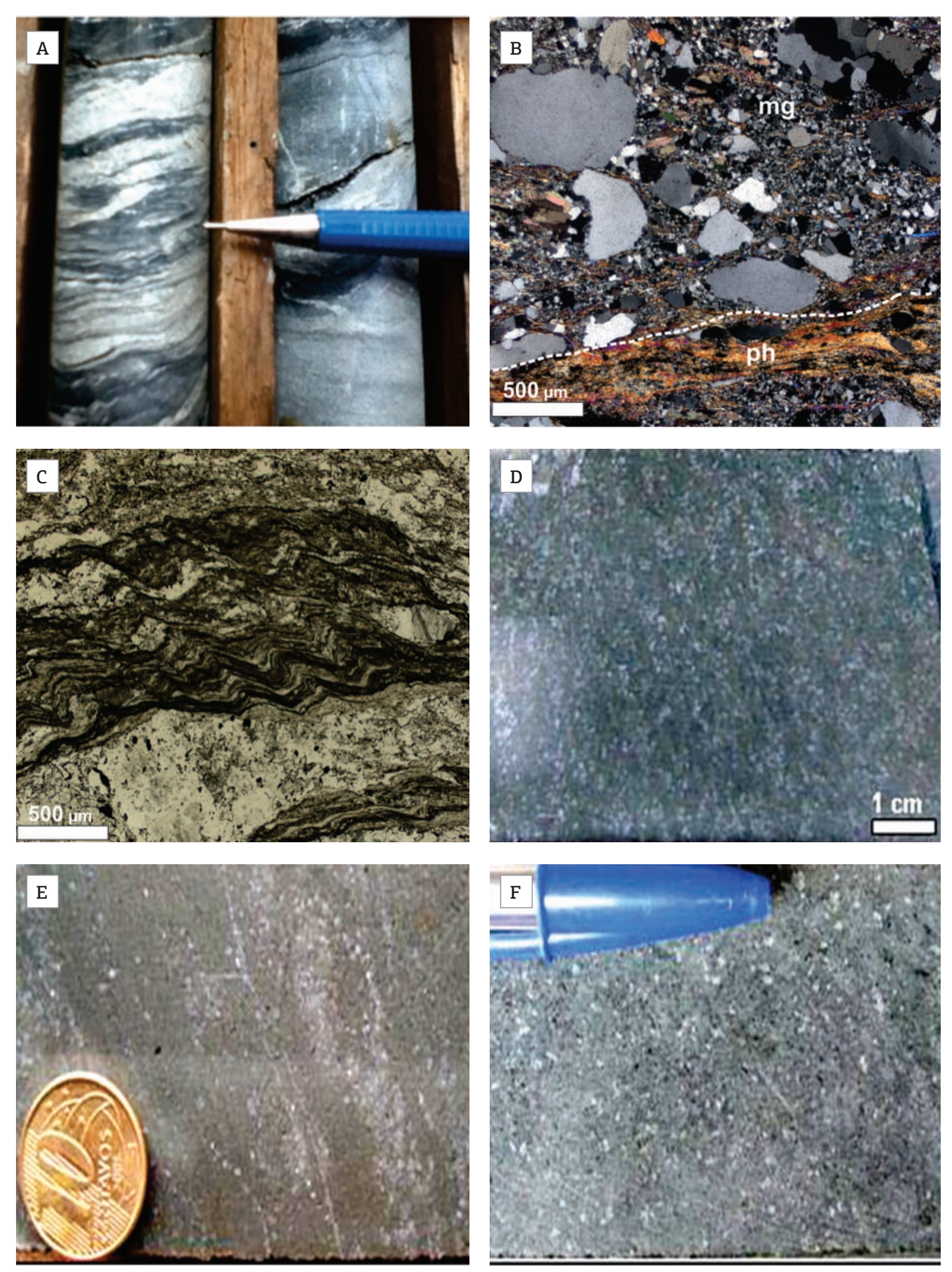

Figure 4. Rhythmic alternation of graded phyllites (ph) and metagraywackes (mg). (A) Macroscopic. (B) Microscopic transmitted light (TL). (C) Photomicrograph of carbonaceous phyllite, TL. Metamafic dikes and sills: (D) Metamafic dikes and sills incipiently altered with pyroxene (MBpx). (E) Metamafic dikes and sills with chlorite and muscovite alteration (MBcl). (F) Metamafic dikes and sills with carbonate alteration (MBcb). 
Table 1. Micro and macroscopic aspects of the Córrego do Sítio Lineament metamafic rocks (modified from Lima 2012)

\begin{tabular}{|c|c|c|c|c|c|c|}
\hline \multirow{2}{*}{$\begin{array}{l}\text { Geologic } \\
\text { unit }\end{array}$} & \multirow{2}{*}{$\begin{array}{c}\text { Thickness } \\
\text { (m) }\end{array}$} & \multirow{2}{*}{$\begin{array}{c}\text { Mineralogy } \\
\text { Essential }\end{array}$} & \multicolumn{4}{|c|}{ Macroscopic characteristics of rocks } \\
\hline & & & Accessories & Center & Intermediate & Border \\
\hline $\begin{array}{l}\text { MBpx }^{1}- \\
\text { incipiently } \\
\text { altered } \\
\text { metamafic } \\
\text { rocks } \\
\text { with relict } \\
\text { pyroxene } \\
\text { (Fig. 4D) }\end{array}$ & 60 to 100 & $\begin{array}{c}\text { Pyroxene } \\
\text { Amphibole } \\
\text { Biotite } \\
\text { Plagioclase } \\
\text { Chlorite } \\
\text { Quartz } \\
\text { Titanite } \\
\text { Muscovite } \\
\text { Carbonate }\end{array}$ & $\begin{array}{l}\text { Magnetite } \\
\text { Ilmenite } \\
\text { Pyrite } \\
\text { Pyrrhotite } \\
\text { Chalcopyrite } \\
\text { Sphalerite } \\
\text { Apatite }\end{array}$ & $\begin{array}{c}\text { Dark green } \\
\text { Medium to coarse- } \\
\text { grained } \\
\text { Preserved ophitic to } \\
\text { subophitic igneous } \\
\text { texture } \\
\text { Chlorite orientation in } \\
\text { cleavage } \\
\text { Rare quartz and } \\
\text { carbonate veinlets }\end{array}$ & $\begin{array}{l}\text { Light to dark green } \\
\text { Medium to coarse- } \\
\text { grained } \\
\text { Chlorite, biotite } \\
\text { and muscovite } \\
\text { aligned along } \\
\text { cleavage } \\
\text { Stockwork with } \\
\text { millimeter quartz- } \\
\text { carbonate veinlets }\end{array}$ & $\begin{array}{c}\text { Light to dark green } \\
\text { Medium to coarse- } \\
\text { grained } \\
\text { Chlorite, biotite } \\
\text { and muscovite } \\
\text { aligned along } \\
\text { cleavage } \\
\text { Dense stockwork } \\
\text { with centimetric } \\
\text { to millimetric } \\
\text { quartz-carbonate } \\
\text { veinlets }\end{array}$ \\
\hline $\begin{array}{l}\mathrm{MBcl}^{2} \\
\text { - metamafic } \\
\text { rocks with } \\
\text { chlorite and } \\
\text { muscovite } \\
\text { alteration } \\
\text { (Fig. 4E) }\end{array}$ & 10 to 40 & $\begin{array}{l}\text { Hornblende } \\
\text { Tremolite- } \\
\text { actinolite } \\
\text { Plagioclase } \\
\text { Chlorite } \\
\text { Epidote } \\
\text { Carbonate } \\
\text { Quartz } \\
\text { Muscovite } \\
\text { Biotite }\end{array}$ & $\begin{array}{l}\text { Magnetite } \\
\text { Titanite } \\
\text { Ilmenite } \\
\text { Rutile } \\
\text { Pyrrhotite } \\
\text { Pyrite } \\
\text { Chalcopyrite }\end{array}$ & $\begin{array}{c}\text { Dark green } \\
\text { Medium to coarse- } \\
\text { grained } \\
\text { Preserved ophitic to } \\
\text { subophitic igneous } \\
\text { texture } \\
\text { Chlorite oriented in } \\
\text { cleavage } \\
\text { Rare quartz and } \\
\text { carbonate veinlets }\end{array}$ & $\begin{array}{l}\text { Light to dark green } \\
\text { Medium to coarse- } \\
\text { grained } \\
\text { Chlorite and } \\
\text { muscovite aligned } \\
\text { along cleavage } \\
\text { Stockwork with } \\
\text { millimeter quartz } \\
\text { and carbonate } \\
\text { veinlets }\end{array}$ & $\begin{array}{c}\text { Light green to grey } \\
\text { Medium to coarse- } \\
\text { grained } \\
\text { Chlorite and } \\
\text { muscovite } \\
\text { orientated along } \\
\text { penetrative } \\
\text { cleavage } \\
\text { Stockwork with } \\
\text { millimeter quartz } \\
\text { and carbonate } \\
\text { veinlets }\end{array}$ \\
\hline $\begin{array}{l}\mathrm{MBcb}^{3} \\
\text { - metamafic } \\
\text { rocks with } \\
\text { chlorite and } \\
\text { carbonate } \\
\text { alteration } \\
\text { (Fig. } 4 \mathrm{~F} \text { ) }\end{array}$ & 0.10 to 7 & $\begin{array}{l}\text { Muscovite } \\
\text { Carbonate } \\
\text { Chlorite } \\
\text { Quartz } \\
\text { Tremolite } \\
\text { Actinolite }\end{array}$ & $\begin{array}{l}\text { Pyrrhotite } \\
\text { Pyrite } \\
\text { Chalcopyrite }\end{array}$ & $\begin{array}{l}\text { Grey to dark grey, m } \\
\text { swarms and radial d } \\
\text { and displaced by E-W } \\
\text { and exhibit incipient } \\
\text { dispersed throughou } \\
\text { sulfosalts may develop }\end{array}$ & $\begin{array}{l}\text { ssive rocks. Thinnest } \\
\text { rections. Their contac } \\
\text { aults. Do not display } \\
\text { histosity. Euhedral ca } \\
\text { the rocks. Quartz, car } \\
\text { euhedral crystals in vu } \\
\text { cleavage is present. }\end{array}$ & $\begin{array}{l}\text { trusion of all. In } \\
\text { may be crosscut } \\
\text { drothermal zoning } \\
\text { onate crystals are } \\
\text { nate, sulfide and } \\
\text { s. Local crenulation }\end{array}$ \\
\hline
\end{tabular}

Local mine names: (1) DB4; (2) DB2, DB3; (3) DB1.

a modal orientation of 60/82. These fractures are centimetre-to-metre spaced and filled by quartz and carbonate (Figs. 5G and 6G).

Shear zones were mapped mainly in the carbonaceous phyllite layers, with the development of S-C structures parallel or sub-parallel to $S_{1-2}$. Faults are well displayed in the carbonaceous phyllite, showing NW-SE strike.

The ore zone is predominantly hosted at the stratigraphic break between metasedimentary and metamafic rocks. Mineralization is associated with intense silicification and narrow, variably deformed, quartz-carbonate-bearing veins parallel to the $S_{1-2}$ foliation (Figs. $7 \mathrm{H}$ and $7 \mathrm{I}$ ). Lodes are generally located within structurally favorable $S_{1-2}$ sites in shear zones and folds, while individual veins are 0.1 to $5 \mathrm{~m}$ thick, locally up to $10 \mathrm{~m}$. The lode gold quartz-carbonate veins are discontinuous both along strike and down dip and are highly boudinaged (Ribeiro et al. 2013, Sequetto-Pereira et al. 2013; Tab. 2). Canale (1999), David (2006), Porto (2008), Lima (2012), Ribeiro et al. (2013) and Sequetto-Pereira et al. (2013) describe the structurally controlled mineralization styles as disseminated, sulfide replacement and associated with quartz-carbonate-sulfide \pm sulfosalts veins.

Smoky quartz in veins containing carbonate-sulfide-sulfosalt is xenoblastic, very deformed, with lobate edges and wavy extinction. Subhedral and polygonal quartz crystals show straight to undulose extinction (Ribeiro et al. 2013). Fine-grained, anhedral carbonate is abundant. Milky quartz is granoblastic and represents a recrystallization product of the smoky quartz; it is commonly concentrated near metamafic dikes and sills. The milky recrystallized quartz forms mosaic textures of polygonal and subhedral crystals, with straight extinction. Fine-grained crystals are associated with fine, anhedral carbonate (Ribeiro et al. 2013).

Many descriptions of the relationship between gold and veins in the older literature of Quadrilátero Ferrífero indicate that gold was most commonly found in the smoky quartz veins (Martins 2011). However, in the Cachorro Bravo deposit, gold is consistently found in both milky and smoky quartz veins, and the same is true for the Laranjeiras deposit, in which gold is most commonly located in sulfide-bearing, 


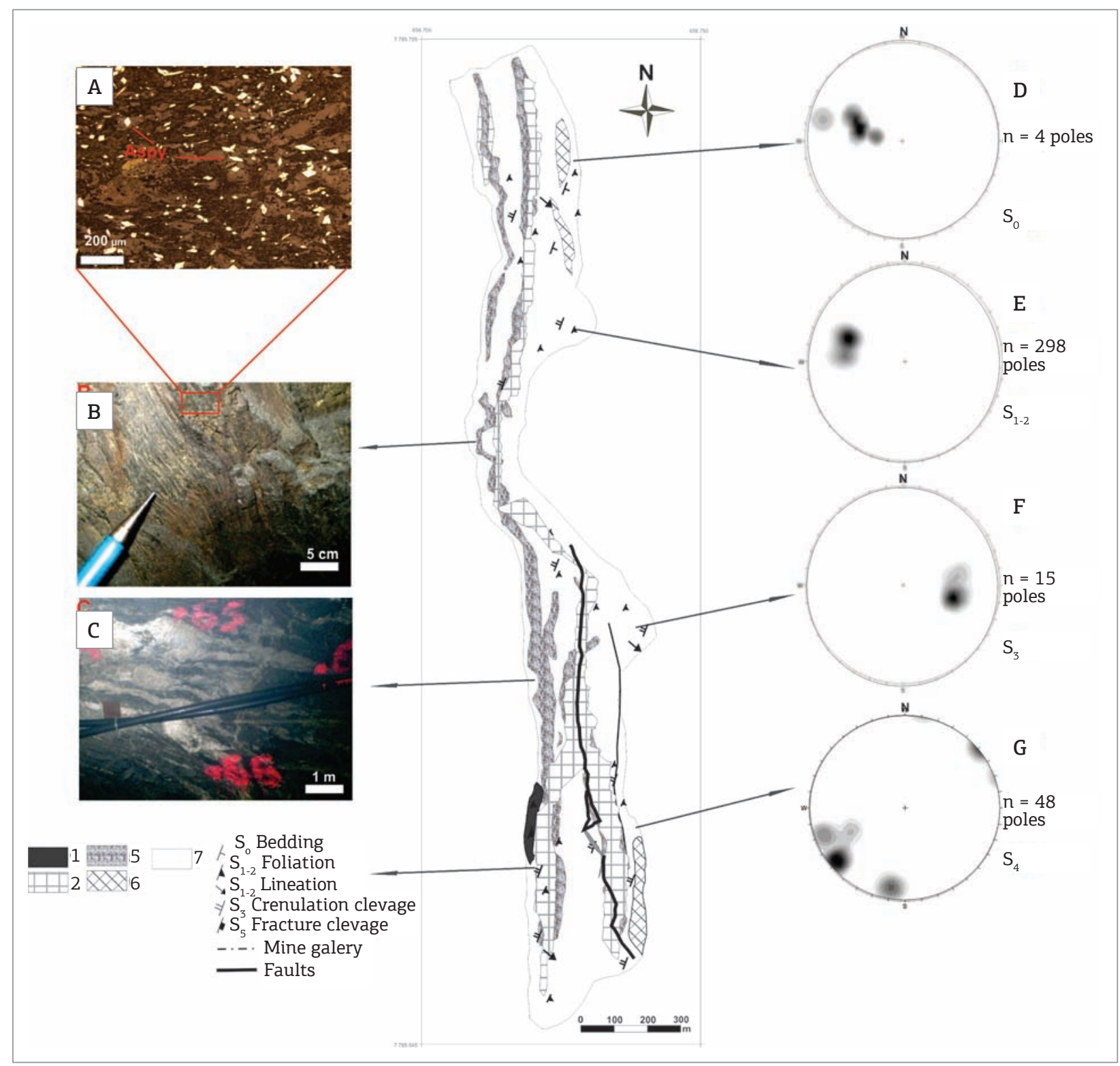

Figure 5. Simplified 1 : 100 scale geological map of mine Gallery CB-658-200/211-south with lithological types (A to C) and structural data (stereograms D to G), Córrego do Sítio intermediate unit, Cachorro Bravo gold deposit. (A) Photomicrograph of disseminated arsenopyrite (Aspy) in metasedimentary rocks (reflected light). (B) Intercalation of phyllite and metagraywacke along bedding $\left(\mathrm{S}_{0}\right)$. (C) White/smoky-quartz-carbonate veins and veinlets in metasedimentary rocks. (D) Bedding $\left(\mathrm{S}_{0}\right)$. (E) Mylonitic foliation $\left(\mathrm{S}_{1-2}\right)$. (F) Crenulation cleavage $\left(\mathrm{S}_{3}\right)$. (G) Fracture cleavage $\left(\mathrm{S}_{5}\right)$.

$\mathrm{S}_{1}$-concordant veins. However, this is not a typical feature of other metasedimentary-hosted vein gold deposits (e.g. Cox et al. 1991).

Mineralogical and textural transformations accompanying wall-rock alteration were observed surrounding the main mineralized vein systems (Fig. 8), although the limits of the alteration zones (Fig. 9) are not always sharp and regular. There are two main distinct hydrothermal alteration assemblages of the host metasedimentary rocks which depend on the proximity to metamafic dikes. Whereas the Cachorro
Bravo deposit is closely limited on both sides by dikes (specifically $\mathrm{MBcl}$ ), these igneous intrusions are located farther away from the Laranjeiras and Carvoaria deposits (Fig. 2). In the former, chlorite and pyrrhotite are present, while at Laranjeiras and Carvoaria berthierite, stibnite and pyrite are part of the distinct mineral assemblage (Figs. 9A and 9B).

The main hydrothermal minerals include quartz, carbonate, white mica, chlorite and accessory rutile, titanite, apatite ilmenite and sphalerite. Minerals in trace amounts include chalcopyrite, galena, sphalerite, sulfosalts and tetrahedrite. 


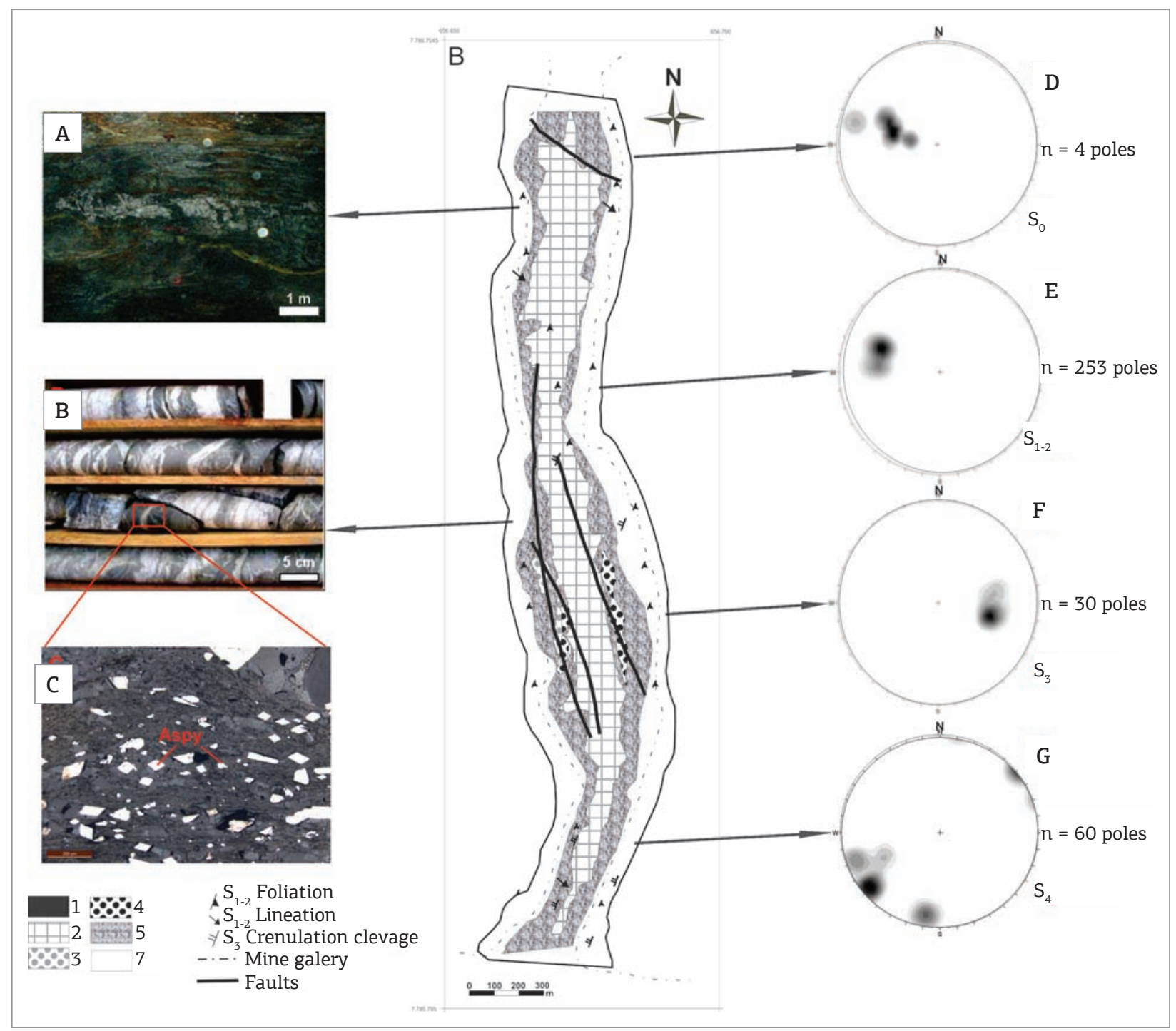

Figure 6. Simplified 1 : 100 scale geological map of mine Gallery CB-711-200/211-south (as in Fig. 5) with lithological types (A to $\mathrm{C}$ ) and structural data (stereograms D to G), Córrego do Sítio intermediate unit, Cachorro Bravo gold deposit. (A) Intercalation of phyllite and metagraywacke along bedding $\left(\mathrm{S}_{0}\right)$. (B) White/smoky-quartzcarbonate veins and veinlets in metasedimentary rocks near the contact with metamafic dikes and sills with chlorite and muscovite alteration ( $\mathrm{MBcl})$. (C) Photomicrograph of disseminated arsenopyrite in metasedimentary rocks (reflected light). (D) Bedding $\left(\mathrm{S}_{0}\right)$. (E) Mylonitic foliation $\left(\mathrm{S}_{1-2}\right)$. (F) Crenulation cleavage $\left(\mathrm{S}_{3}\right)$. (G) Fracture cleavage $\left(\mathrm{S}_{5}\right)$.

The hydrothermal assemblage in metamafic rocks is chlorite, epidote, calcite, quartz, muscovite and rare biotite. The accessories are magnetite, ilmenite, rutile, pyrrhotite, pyrite, chalcopyrite, galena and sphalerite (Fig. 10). In transitional zones, the consumption of carbonaceous matter is almost complete (Porto et al. 2006, Porto 2008) with bleaching of these carbon-rich phyllites.

The mineralization type recognized along the mapped area is composed of white/smoky-quartz-carbonate veins and veinlets in metasedimentary rocks near the contact with $\mathrm{MBcl}$ dikes, containing sericite, chlorite and carbonate and showing transitional zones with dikes. Arsenopyrite is the main sulfide, but pyrrhotite is also significant in proximity to dikes.

Based on the mineralogical composition and mineral textures, Lima (2012) identified gold in five associations:

1. free and disseminated electrum in quartz-carbonate veins;

2. included in disseminated arsenopyrite, generally parallel to the main foliation and associated with phyllosilicates, chlorite, sericite or muscovite; submicroscopic gold is observed in subhedral arsenopyrite crystals, suggesting the presence of invisible gold (Porto 2008); 

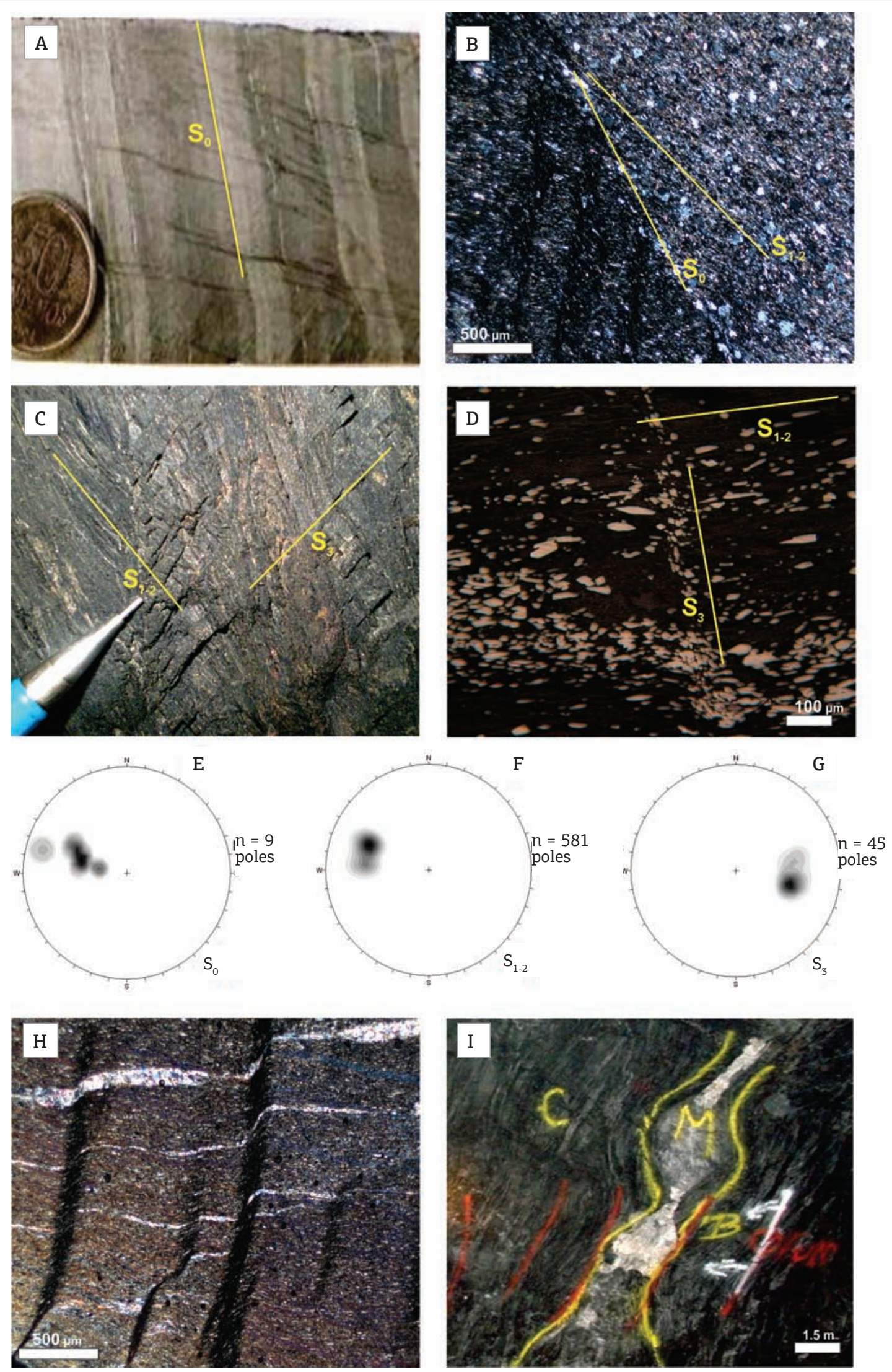

Figure 7. Structural data from the Córrego do Sítio auriferous lineament. (A, B, E) Bedding $\left(\mathrm{S}_{0}\right)$. (B) With transmitted light. (C) With reflected light. (D, F) Mylonitic foliation $\left(S_{1-2}\right)$. (C, D, G) Crenulation cleavage $\left(S_{3}\right)$. (H) With transmitted light. (I) Pinch-and-swell mineralized flattened veins and veinlets (M) of Cachorro Bravo deposit (C and B in the picture). 
Table 2. Synthesis of vein characteristics modified from Ribeiro et al. (2013) and Sequetto-Pereira et al. (2013)

\begin{tabular}{|c|c|c|c|c|c|c|c|c|}
\hline \multirow{2}{*}{ Type } & \multicolumn{2}{|c|}{ Reference } & \multirow{2}{*}{ Mineralogy } & \multirow{2}{*}{$\begin{array}{l}\text { Thickness } \\
\text { (cm) }\end{array}$} & \multirow{2}{*}{ Host rock } & \multirow{2}{*}{$\begin{array}{l}\text { Vein } \\
\text { texture }\end{array}$} & \multirow{2}{*}{ Orientation } & \multirow{2}{*}{$\begin{array}{l}\text { Associated } \\
\text { structure }\end{array}$} \\
\hline & $\begin{array}{l}\text { Ribeiro } \\
\text { et al. } \\
(2013)^{*}\end{array}$ & $\begin{array}{l}\text { Sequetto- } \\
\text { Pereira } \\
\text { et al. (2013) }\end{array}$ & & & & & & \\
\hline \multirow{3}{*}{$\begin{array}{l}\text { Early-stage } \\
\text { alteration, } \\
\text { mineralized } \\
\text { veins }\end{array}$} & \multirow{3}{*}{ V1 } & V1a & $\begin{array}{l}\text { Smoky quartz- } \\
\text { ankerite- } \\
\text { arsenopyrite- } \\
\text { pyrite-gold }\end{array}$ & \multirow{3}{*}{$1-600$} & \multirow{3}{*}{$\begin{array}{l}\text { Metagraywacke, } \\
\text { schist and phyllite }\end{array}$} & $\begin{array}{l}\text { Pinch-and- } \\
\text { swell }\end{array}$ & $120 / 70$ & \multirow{3}{*}{$\begin{array}{l}\text { Parallel to } \\
\text { foliation } \mathrm{S}_{1-2} \\
\text { Folded with } \\
\text { axial- plane } \\
\text { foliation } \\
\text { Shear veins }\end{array}$} \\
\hline & & V1b & $\begin{array}{l}\text { Milky quartz- } \\
\text { ankerite- } \\
\text { arsenopyrite- } \\
\text { pyrite- } \\
\text { pyrrhotite-free } \\
\quad \text { gold }\end{array}$ & & & Massive & $120 / 70$ & \\
\hline & & V1c & $\begin{array}{l}\text { Laminated } \\
\text { smoky or milky } \\
\text { quartz with } \\
\text { pyrite gold }\end{array}$ & & & Granulated & $120 / 70$ & \\
\hline \multirow{6}{*}{$\begin{array}{l}\text { Later-stage } \\
\text { veins (non- } \\
\text { mineralized) }\end{array}$} & \multirow[b]{2}{*}{ V2 } & V2a & $\begin{array}{l}\text { Milky quartz- } \\
\text { (subordinate) } \\
\text { ankerite }\end{array}$ & Irregular & $\begin{array}{l}\text { Metagraywacke, } \\
\text { schist and phyllite }\end{array}$ & Massive & $\begin{array}{l}70 / 70 \text { and } \\
160 / 80\end{array}$ & $\begin{array}{l}\text { Diagonal to } \\
\text { foliation } \mathrm{S}_{3}\end{array}$ \\
\hline & & V2b & $\begin{array}{c}\text { Quartz-ankerite- } \\
\text { pyrite }\end{array}$ & $2-300$ & $\begin{array}{l}\text { Metagraywacke, } \\
\text { schist and phyllite }\end{array}$ & Massive & $295 / 40$ & $\begin{array}{l}\text { Parallel to } \\
\text { foliation } \mathrm{S}_{3} \\
\text { Extensional } \\
\quad \text { veins }\end{array}$ \\
\hline & \multirow{2}{*}{ V3 } & V3a & $\begin{array}{c}\text { Milky quartz- } \\
\text { (subordinate) } \\
\text { ankerite }\end{array}$ & \multirow{2}{*}{$1-20$} & \multirow{2}{*}{$\begin{array}{l}\text { Metagraywacke, } \\
\text { schist and phyllite }\end{array}$} & Fibrous & $70-130 / 80$ & \multirow{2}{*}{$\begin{array}{c}\text { Parallel to } \\
\text { foliation } \mathrm{S}_{4} \\
\text { Fracture veins }\end{array}$} \\
\hline & & V3b & $\begin{array}{c}\text { Milky quartz- } \\
\text { ankerite veins } \\
\text { and schist } \\
\text { fragments }\end{array}$ & & & Breccia & $60 / 70$ & \\
\hline & - & V4 & $\begin{array}{l}\text { Varied } \\
\text { mineralogy }\end{array}$ & Irregular & $\begin{array}{l}\text { Metagraywacke, } \\
\text { schist and phyllite }\end{array}$ & Massive & $300 / 30$ & $\begin{array}{l}\text { Parallel to } \\
\text { foliation } \mathrm{S}_{3}\end{array}$ \\
\hline & V4 & V5 & $\begin{array}{c}\text { Quartz- } \\
\text { carbonate-calcite }\end{array}$ & $1-15$ & $\begin{array}{l}\text { Metamafic dikes } \\
\text { and sills }\end{array}$ & $\begin{array}{l}\text { Shear veins/ } \\
\text { stockwork }\end{array}$ & $90 / 80$ & $\begin{array}{l}\text { Varied } \\
\text { structures } \\
\text { Extensional } \\
\text { veins }\end{array}$ \\
\hline
\end{tabular}

${ }^{*}$ Chronological classification

3. included in berthierite;

4. included in pyrite or pyrrhotite that are disseminated parallel to the main foliation in micaceous portions;

5. included in silicates, such as quartz or muscovite.

Sulfides are present mainly along the edges of veins, with pyrite being the most common (Lima 2012). Three generations of pyrite are recognized:

1. isolated and disseminated pyrite in carbonaceous layers, in non-mineralized zones, in circular or rounded aggregates that may be folded and partly disintegrated (Fig. 11A);
2. \pm porous pyrite crystals, which may contain gold, associated with a myriad of other sulfide minerals, commonly displaying irregular boundaries of smooth pyrite; porous pyrite may be replaced by arsenopyrite (Figs. $11 \mathrm{~B}$ and $11 \mathrm{C})$;

3. late-stage, smooth euhedral pyrite in isolated crystals that apparently result from borders of the porous pyrite (Fig. 11D).

Early-stage porous pyrrhotite is sometimes replaced by smooth pyrrhotite (Fig. 11D). 


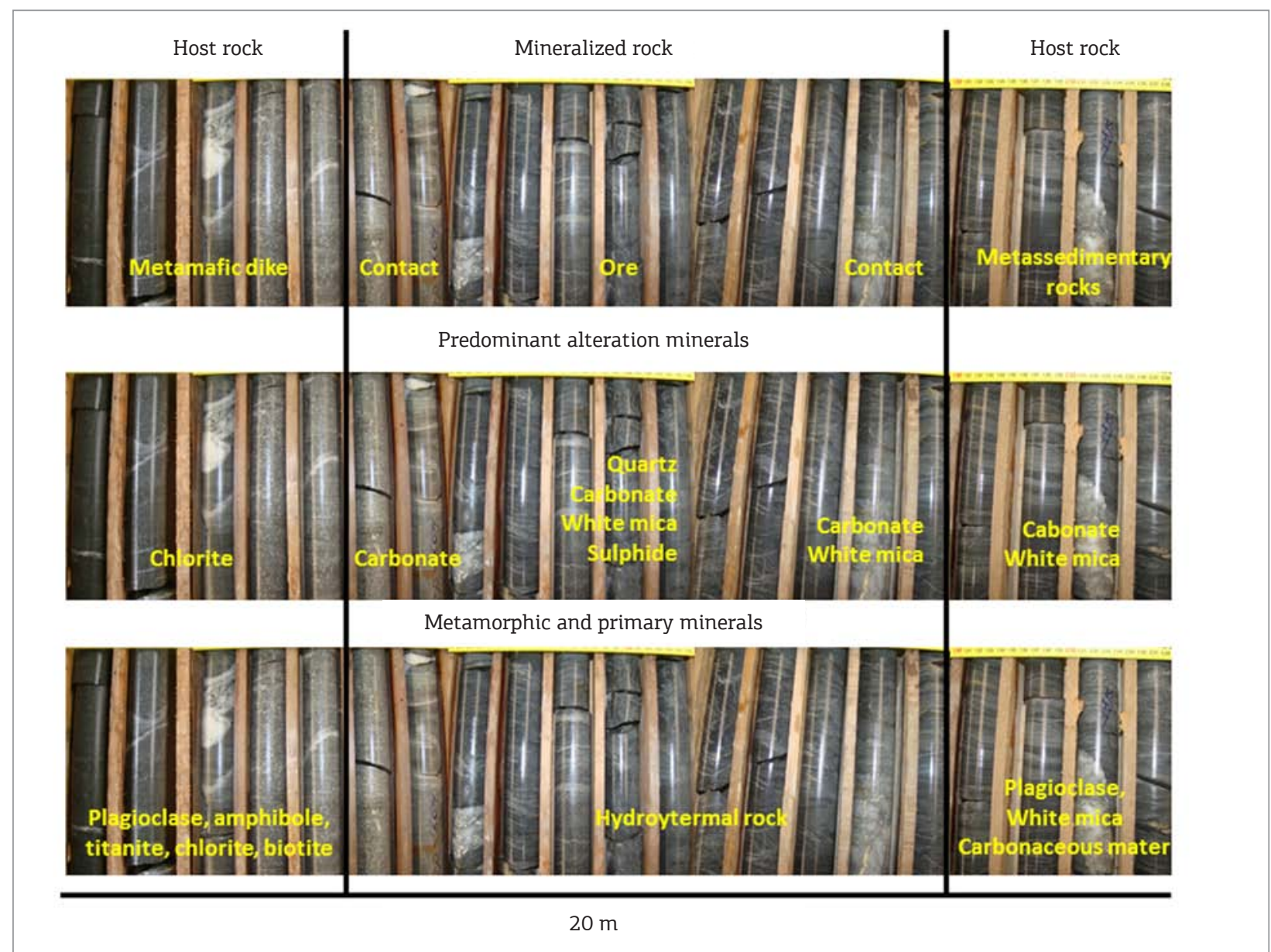

Figure 8. Hydrothermal alteration zones along the contact between metasedimentary and metamafic rocks (modified from Porto 2008).

Arsenopyrite is the predominant gold-associated sulfide in the Cachorro Bravo deposit and is always present in the carbonaceous phyllites, where in veins it is also related to phyllite portions. Arsenopyrite forms from pyrite in mineralized metasedimentary rock zones away from metamafic dikes and sills, or from pyrrhotite in mineralized transitional zones between metasedimentary rock zones and metamafic dikes and sills. Two generations of arsenopyrite are identified: 1. euhedral and subhedral, smooth, very fine-grained crystals, in prisms or needles (Fig. 11E), or

2. anhedral to subhedral crystals (Fig. 11F) associated with pyrite or pyrrhotite, preserving the original habit and porosity of the latter sulfides.

Stibinite and berthierite are commonly associated with the main sulfides in the mineralized metasedimentary rocks, mainly in smoky quartz-carbonate-sulfide-sulfosalt veins. As indicated by Lima (2012), both porous pyrrhotite and pyrite occur in the core of sulfide crystal aggregates
(Fig. 11G), with berthierite being the most abundant. This opaque mineral is present mainly in millimetric, subhedral to euhedral crystals in vugs, with inclusions of anhedral pyrrhotite, porous pyrite, anhedral arsenopyrite, chalcopyrite, sphalerite and gold.

Microprobe studies undertaken by Lima (2012) and Ribeiro et al. (2013) detailed a series of phases that are not identified under the microscope, including sphalerite, cobaltite, cinnabar, tetrahedrite, boulangerite group minerals and ullmanite.

\section{DISCUSSION AND CONCLUSIONS}

The Archean Córrego do Sítio Unit is the most abundant metasedimentary unit of the Rio das Velhas greenstone belt in the Quadrilátero Ferrífero region (Baltazar \& Zuchetti 2007) and occurs as a metamorphosed turbidite sequence. Baltazar and Zuchetti (2007) included this unit 


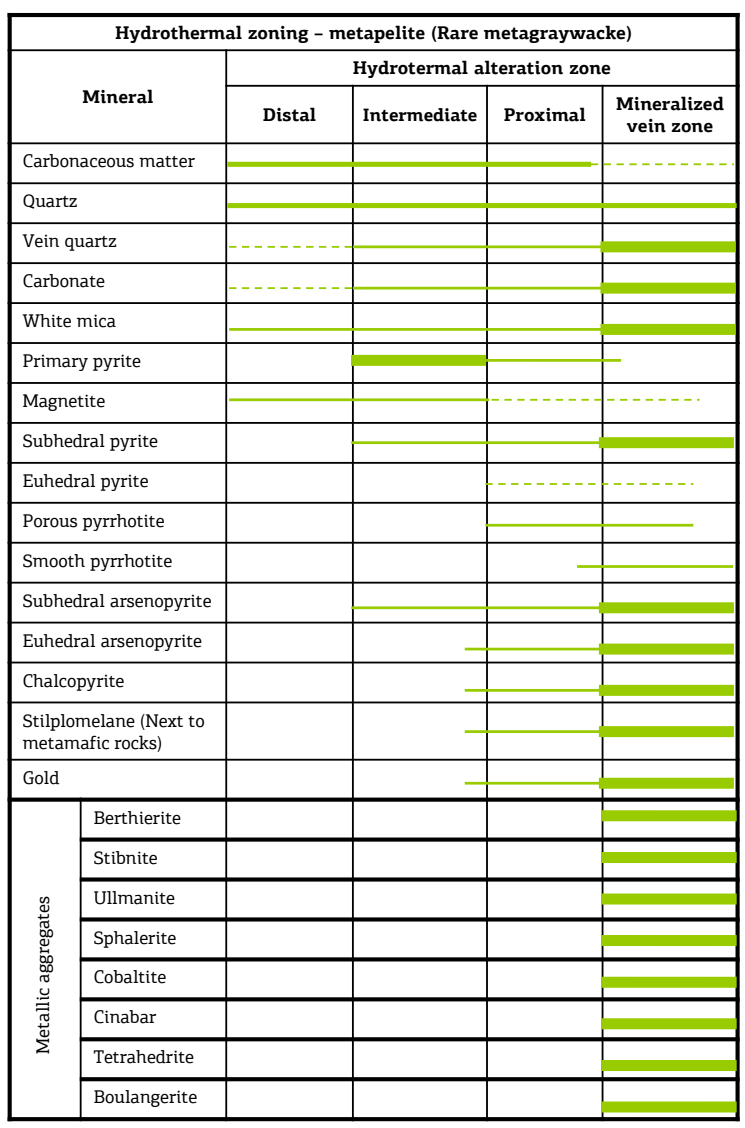

\begin{tabular}{|c|c|c|c|c|c|}
\hline \multicolumn{6}{|c|}{ Hydrothermal zoning - metagraywacke (rare metapelite) } \\
\hline \multirow{2}{*}{\multicolumn{2}{|c|}{ Mineral }} & \multicolumn{4}{|c|}{ Hydrotermal alteration zone } \\
\hline & & Distal & Intermediate & Proximal & $\begin{array}{l}\text { Mineralized } \\
\text { vein zone }\end{array}$ \\
\hline \multicolumn{2}{|c|}{ Carbonaceous matter } & & & & $\ldots-\cdots$ \\
\hline \multicolumn{2}{|c|}{ Quartz } & & & & \\
\hline \multicolumn{2}{|c|}{ Vein quartz } & - & & & \\
\hline \multicolumn{2}{|c|}{ Carbonate } & & & & \\
\hline \multicolumn{2}{|c|}{ Magnetite } & & & -1 & -- \\
\hline \multicolumn{2}{|c|}{ White mica } & & & & 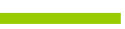 \\
\hline \multicolumn{2}{|c|}{ Plagioclase } & & --- & $-\cdots$ & \\
\hline \multicolumn{2}{|c|}{ Primary pyrite } & & & & \\
\hline \multicolumn{2}{|c|}{ Subhedral pyrite } & & & & 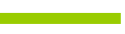 \\
\hline \multicolumn{2}{|c|}{ Euhedral pyrite } & & & & \\
\hline \multicolumn{2}{|c|}{ Porous pyrrhotite } & & & & \\
\hline \multicolumn{2}{|c|}{ Smooth pyrrhotite } & & - & & \\
\hline \multicolumn{2}{|c|}{ Subhedral arsenopyrite } & & & & \\
\hline \multicolumn{6}{|c|}{ Euhedral arsenopyrite } \\
\hline \multicolumn{6}{|c|}{$\begin{array}{l}\text { Stilplomelane (next to } \\
\text { metamafic rocks) }\end{array}$} \\
\hline \multirow{8}{*}{ 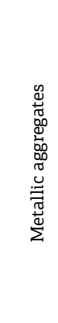 } & Berthierite & & & & \\
\hline & Stibnite & & & & \\
\hline & Ullmanite & & & & \\
\hline & Sphalerite & & & & \\
\hline & Cobaltite & & & & \\
\hline & Cinabar & & & & \\
\hline & Tetrahedrite & & & & \\
\hline & \begin{tabular}{|l|} 
Boulangerite \\
\end{tabular} & & & & \\
\hline
\end{tabular}

Figure 9. Hydrothermal paragenic zoning, including the main sulfides, associated with gold in (A) Metapelite. (B) Metagraywackes, Córrego do Sítio auriferous lineament. Line thicknesses represent schematically the relative quantities of each mineral deposited (constructed also including data from Porto 2008 and Lima 2012).

\begin{tabular}{|l|l|l|l|}
\hline \multicolumn{4}{|c|}{ Hydrothermal zoning } \\
\hline Mineral & Edge & Intermediate & Center \\
\hline Quartz & & & \\
\hline Carbonate & & & \\
\hline White mica & & & \\
\hline Chlorite & & & \\
\hline Titanite & & & \\
\hline Primary pyrite & & & \\
\hline Porous pyrrhotite & & & \\
\hline Chalcopyrite & & & \\
\hline Gold & & & \\
\hline
\end{tabular}

Figure 10. Hydrothermal paragenic zoning, including the main sulfides in metamafic rocks of the Córrego do Sítio auriferous lineament. Line thicknesses represent schematically the relative quantities of each mineral deposited (constructed also including data from Porto 2008 and Lima 2012). in their re-sedimented association, which contains greywacke, phyllites, and banded iron-formation. These facies represent deposition within different submarine environments. Depositional characteristics in the Rio das Velhas Greenstone Belt are similar to those of other Archean sediment-dominated greenstone belts in the world (e.g. Padgham 1992, Krapez 1993, Jackson et al. 1994, Ootes et al. 2011).

The E portion of the Rio das Velhas Greenstone Belt is dominated by a package of turbiditic metasedimentary rocks consisting of alternating greenschist facies metagraywackes and phyllites. Metamafic dikes and sills have an NNE-SSW direction and are divided into MBpx and hydrothermally altered rocks locally mineralized in gold. The increased mineralization is related to the proximity of metamafic dikes and sills.

Four deformation events affected the mine sequence and these are in part progressive. Event $\mathrm{D}_{1}$ is characterized by a progressive foliation $S_{1-2}$, striking NNE and dipping to ESE, producing tight, asymmetric, isoclinal and disharmonic kink 

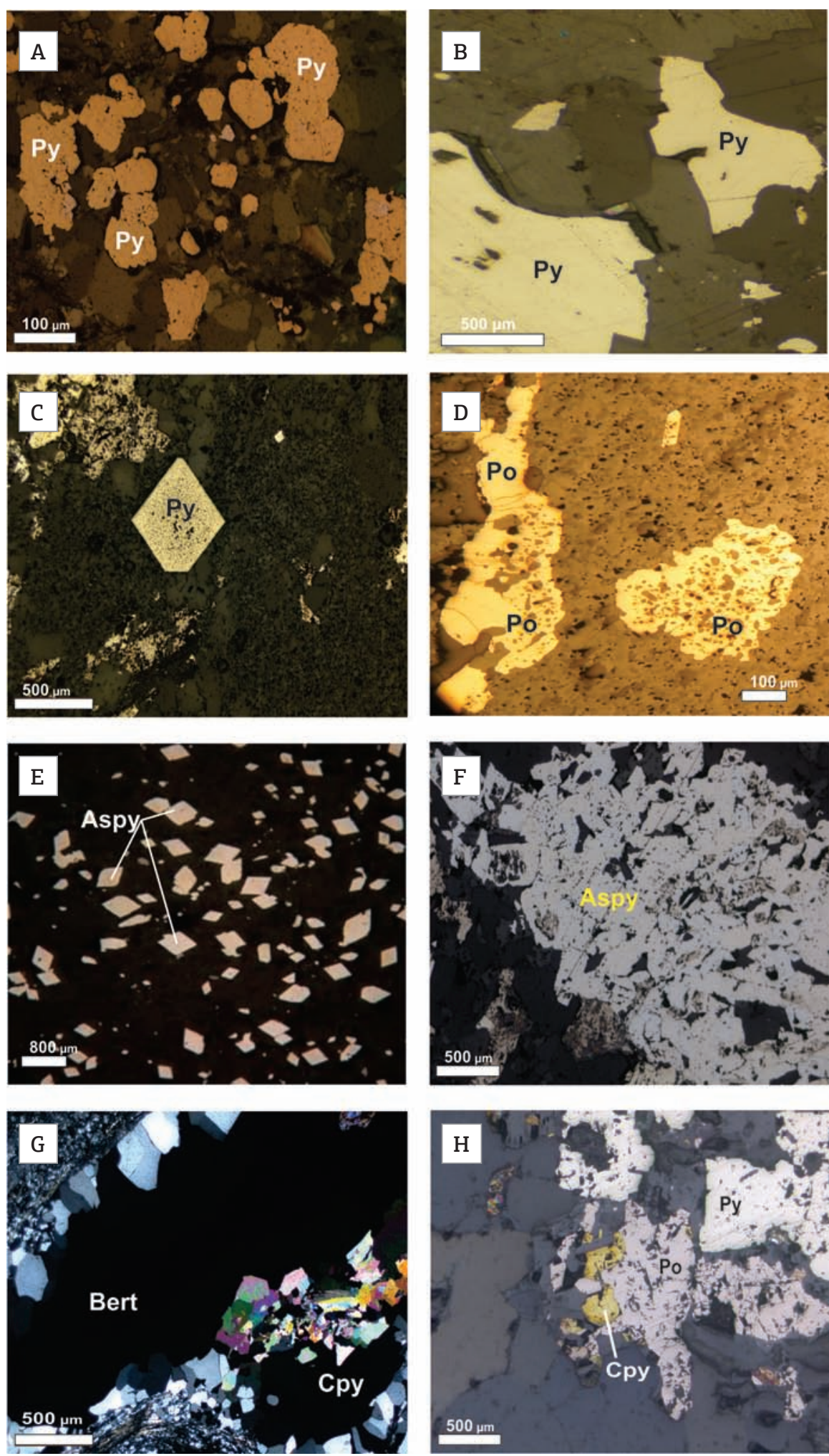

Figure 11. Generations of sulfides associated with the Cachorro Bravo gold deposit, Córrego do Sítio auriferous lineament. (A) Flamboidal pyrite (Py) reflected light. (B) \pm Porous pyrite (Py) reflected light. (C) Euhedral pyrite (Py) transmitted light). (D) Early-stage, porous pyrrhotite (Po) replaced by smooth pyrrhotite (Po) reflected light. (E) Euhedral acicular arsenopyrite (Aspy) reflected light. (F) Anhedral-to-subhedral arsenopyrite (Aspy) reflected light. (G) Subhedral-to-euhedral berthierite (Bert) in vugs (transmitted light). (H) Sulfide crystals aggregates with chalcopyrite (Cpy) reflected light. 
folds; $\mathrm{D}_{2}$ is typified by a crenulation cleavage and a spaced crenulation cleavage $S_{3}$, which strikes NNE crosscutting the regional foliation $S_{1-2}$ at a high angle to the NW; $\mathrm{D}_{3}$ is represented by large-scale, open folds, arching $S_{0}, S_{1-2}$ and $S_{3}$. These structures may represent more recent orogeny; and $\mathrm{D}_{4}$ has parallel fractures, spaced from centimetres to metres along with open folds or subordinate kink folds with high angle vertical axial plane, striking mainly towards NW.

Two different vein types are important to mineralization: 1. smoky-quartz-carbonate-sulfide-sulfosalt veins, which are highly deformed, and

2. milky-quartz-carbonate veins that represent recrystallization of the smoky quartz-carbonate veins.

Sequetto-Pereira et al. (2013) and Ribeiro et al. (2013) classified the mineralized veins as associated with smoky and milky quartz veins, with the latter only being observed as unmineralized veins.

The main deposits have a paragenesis common in other turbidite-hosted deposits worldwide (e.g. Bendigo-Ballarat, Australia, Gao \& Kwat 1995; Wattle Gully Deposit, Australia, Cox et al. 1995; Lachlan Fold Belt, Australia, Bierlein et al. 1998; Jaclyn Deposit, Newfoundland Appalachians, Sandeman et al. 2010), where gold occurs both as free grains and in association with arsenopyrite and pyrite, or stibnite in some lodes.

In the hydrothermal zones, arsenopyrite forms after pyrite or pyrrhotite, both locally seen to originate from the consumption of magnetite. Near the metamafic dikes, especially in the Cachorro Bravo deposit, arsenopyrite develops after pyrrhotite in mineralized veins and veinlets. The pyrrhotite/ arsenopyrite association along dike zones may reflect local conditions of relatively higher temperature. Arsenopyrite after pyrite is typical of alteration zones far from metamafic dikes, where veins are dominated by smoky quartz-carbonate veins with berthierite, stibnite and pyrite, and gold. In the Sb-Au-quartz veins, berthierite and stibnite are the most abundant $\mathrm{Sb}$-bearing minerals. This mineralization stage is mainly observed in carbonaceous phyllites and has a gold-dominated association with porous arsenopyrite, which is the predominant gold-associated sulfide in the Cachorro Bravo deposit. During the last three decades, numerous studies have recognized a close association between $\mathrm{Au}$ and $\mathrm{As}$ in arsenopyrite (Cook \& Chryssoulis 1990, Arehart et al.
1993, Friedl et al. 1995, Simon et al. 1999, Ye et al. 2001, Emsbo et al. 2003, Palenik et al. 2004).

Nevertheless, the mapped galleries illustrate that detailed geological studies are capable of detecting mineralization and wall-rock alteration zones around these deposits. The increase in the intensity of the hydrothermal alteration with the proximity to quartz lodes is indicated by the bleaching of the wall rocks and the abundance of disseminated pyrite, pyrrhotite and arsenopyrite, as well as stibnite and berthierite. The recognition of wall-rock alteration has implications for turbidite-hosted gold exploration, which is - due to the nature of the mineralization style - commonly a high-risk affair and often based solely on structural interpretation.

The data presented provide some structural and petrographic similarities on models for formation of these deposits, assuming that the Cachorro Bravo, Laranjeiras and Carvoaria are representative of the metaturbidite-hosted lode-gold deposits. Vein formation and mineralization occurred in multiple episodes, as suggested by Sequetto-Pereira $e t$ al. (2013). The fluid was most likely modified during ascent to this structural level and later interaction with wall rocks. This is consistent with the conclusions of other studies directed at lode-gold deposits of Archean to Phanerozoic age (e.g. Goldfarb et al. 1988, 1991).

\section{ACKNOWLEDGMENTS}

We thank all members of AngloGold Ashanti Córrego do Sítio Mineração (AGACSM) for their help, logistic and financial support, especially Rodrigo Martins, who has maintained his commitment to our research group. This research is fully financed by Conselho Nacional de Desenvolvimento Científico e Tecnológico (CNPq), Vale and AGABM. We acknowledge the support of Universidade Federal de Minas Gerais (UFMG), Coordenação de Aperfeiçoamento de Pessoal de Nível Superior (CAPES), Fundação de Amparo à Pesquisa do Estado de Minas Gerais (FAPEMIG) and Fundação de Desenvolvimento da Pesquisa (FUNDEP). We also thank Prof. C.A. Rosière, for his valuable comments and corrections, as well as Robert Pankhurst and two anonymous referees for their important and constructive comments.

\section{REFERENCES}

Almeida F.F.M. 1976. Estruturas do Pré-Cambriano Inferior Brasileiro. In: $29^{\circ}$ Congresso Brasileiro de Geologia, 1976. Ouro Preto, Resumos SBG, p. 201-202.

Arehart G.B., Chryssoulis S.L., Kesler S.E. 1993. Gold and arsenic in iron sulfides from sediment-hosted disseminated gold deposits: implications for depositional processes. Economic Geology, 88: 171-185.
Baltazar O.F. \& Silva S.L. 1998a. Mapa geológico integrado do supergrupo Rio das Velhas, escala 1: 100.000. Brasília, Departamento Nacional de Produção Mineral, CPRM.

Baltazar O.F. \& Silva S.L. 1998b. Projeto Rio das Velhas - texto explicativo do mapa geológico integrado, escala 1: 100.000. Belo Horizonte, Departamento Nacional de Produção Mineral. 126 p. 
Baltazar O.F. \& Zucchetti M. 2007. Lithofacies associations and structural evolution of the Archean Rio das Velhas greenstone belt, QuadriláteroFerrífero, Brazil: a review of the setting of gold deposits. Ore Geology Reviews, 32(3-4):471-499.

Bierlein F.P., Fuller T., Stuwel K., Arne D.C., Keays R.R. 1998. Wallrock alteration associated with turbidite-hosted gold deposits examples from Central Victoria. Ore Geology Reviews, 13(1-5):345-380.

Bouma A.H. 1983. Intraslope basins in northwest Gulf of Mexico: a key to ancient submarine canyons and fans. American Association of Petroleum Geologists Special Publication, 32:567-581.

Canale A.L. 1999. Geologia do depósito Córrego do Sítio, Quadrilátero Ferrífero $(M G)$, e caracterização mineralógica do minério sulfetado. MS Dissertation, Universidade Federal do Rio Grande do Sul, Porto Alegre, $142 \mathrm{p}$.

Condie K.C. 1981. Archean greenstone belts. Amsterdam, Elsevier, $433 \mathrm{p}$

Cook N.J. \& Chryssoulis S.L. 1990. Concentrations of "invisible" gold in the common sulfides. Canadian Mineralogist, 28:1-16.

Cox S.F., Sun S.S., Etheridge M.A., Wall V.J., Potter T.F. 1995. Structural and geochemical controls on the development of turbidite-hosted gold quartz vein deposits, Wattle Gully mine, central Victoria, Australia. Economic Geology, 90:1722-1746.

Cox S.F., Wall V.J., Etheridge M.A., Potter T.F. 1991. Deformational and metamorphic processes in the formation of mesothermal veinhosted gold deposits - examples from the Lachlan Fold Belt in Central Victoria, Australia. Ore Geology Reviews, 6(5):391-423.

David M.E.V. 2006. Composição isotópica de Pb, Sr e Nd da mineralização de ouro do depósito Córrego do Sítio, Quadrilátero Ferrífero (MG): implicações na modelagem conceitual, MS Dissertation, Instituto de Geociências, Universidade de São Paulo, São Paulo, 76 p.

Dorr II J.V.N. 1969. Physiographic, stratigraphic and structural development of the Quadrilátero Ferrífero, Minas Gerais, Brazil. U.S. Geological Survey Professional Paper, 614(A):1-110.

Dorr II J.V.N., Gair J.E., Pomerene J.G., Rynearson G.A. 1957. Revisão da estratigrafia pré-cambriana do Quadrilátero Ferrífero. v. 81. Brasília, Divisão de Fomento da Produção Mineral.

Emsbo P., Hofstra A.H., Lauha E.A., Griffin G.L., Hutchinson R.W. 2003. Origin of high-grade gold ore, source of ore fluid components, and genesis of the Meikle and neighboring Carlin-type deposits, northern Carlin trend, Nevada. Economic Geology, 98:1069-1100.

Friedl J., Wagner F.E., Wang N. 1995. On the chemical state of combined gold in sulfidic ores: conclusions from Mössbauer source experiments. Neues Jahrbuch fur Mineralogie, 169:279-290.

Gao Z.L. \& Kwat T.A.P. 1995. Turbidite-hosted gold deposits in the Bendigo-Ballarat and Melbourne zones, Australia. 1. Geology, mineralisation, stable isotopes, and implications for exploration. International Geology Review, 37:910-944.

Goldfarb R.J., Leach D.L., Pickthorn WJ., Paterson C.J. 1988. Origin of lode-gold deposits of the Juneau gold belt, southeastern Alaska. Geology, 16:440-443.

Goldfarb R.J., Newberry R.J., Pickthorn W.J., Gent C.A. 1991. Oxygen, hydrogen, and sulfur isotope studies in the Juneau gold belt, southeastern Alaska: constraints on the origin of the hydrothermal fluids. Economic Geology, 86:66-80.

Groves D.I., Goldfarb R.J., Gebre-Marian M., Hagemann S.G., Robert F. 1998. Orogenic gold deposits: a proposed classification in the context of their distribution and relationship to other gold deposit types. Ore Geology Reviews, 13:7-27.
Herz N. 1970. Gneissic and igneous rocks of the QuadriláteroFerrífero, Minas Gerais, Brazil. U.S. Geological Survey Professional Paper, 641(B):1-58.

Jackson S.L., Fyona A.J., Corfub F. 1994. Review of Archean supracrustal assemblages of the southern Abitibi greenstone belt in Ontario, Canada: products of microplate interaction within a largescale plate-tectonic setting. Precambrian Research, 65:183-205.

Krapez B. 1993. Sequence stratigraphy of the Archaean supracrustal belts of the Pilbara Block, Western Australia. Precambrian Research, 60:1-45.

Lima L.C. 2012. Depósito LODE Au-As-Sb Laranjeiras, em metaturbitos do Grupo Nova Lima, Quadrilátero Ferrífero, Minas Gerais. MS Dissertation, Instituto de Geociências, Universidade Federal de Minas Gerais, Belo Horizonte, 306 p.

Lobato L.M., Baltazar O.F., Reis L.B., Achtschin A.B., Baars F.J., Timbó M.A., Berni G.V., Mendonça B.R.V., Ferreira D.V. 2005. Projeto Geologia do Quadrilátero Ferrífero - integração e correção cartográfica em SIG com nota explicativa. Belo Horizonte, CODEMIG. 1 CD-ROM.

Lobato L.M., Ribeiro Rodrigues L.C., Souza Costa M.N., Martins R., Lehne E., Tassinari C.C.G., Vieira F.W.R., Biasi E.E.. Silva R.C.F., Pereira V.C.A., Noce C.M. 2001. Depósito de ouro Cuiabá, Quadrilátero Ferrífero, Minas Gerais. In: Departamento Nacional de Produção Mineral, Agência para o Desenvolvimento Tecnológico da Indústria Mineral Brasileira, Caracterização de depósitos auríferos em distritos mineiros brasileiros, Brasília, DNPM/ADIMB, 77 p.

Martins B.S. 2011. Controle da mineralização aurífera de Lamego, Sabará, Quadrilátero Ferrífero, MG. MS Dissertation, Instituto Geociências, Universidade Federal de Minas Gerais, Belo Horizonte, $254 \mathrm{p}$

Ootes L., Morelli R.M., Creaser R.A. Lentz D.R., Davis H.W.J. 2011. The timing of Yellowknife gold mineralization: a temporal relationship with crustal anatexis? Economic Geology, 106:713-720.

Padgham W.A. 1992. Mineral deposits in the Archean Slave Structural Province: lithological and tectonic setting. Precambrian Research, 58:1-24

Palenik C.S., Utsunomiya S., Reich M., Kesler S.E., Wang L.M., Ewing R.C. 2004. "Invisible" Au revealed: direct imaging of Au nanoparticles in a Carlin-type deposit. American Mineralogist, 89:1359-1366.

Porto C.G. 2008. A mineralização aurífera do depósito Córrego do Sítio e sua relação com o enxame de diques metamáficos no corpo CACHORRO BRAVO - Quadrilátero Ferrífero - Minas Gerais. MS Dissertation, Universidade Federal de Minas Gerais, Belo Horizonte, $117 \mathrm{p}$.

Porto C.G., Lobato L.M., Massucatto A.J. 2006. Caracterização da mineralização aurífera de Córrego do Sítio. Sessão Pôster. In: II Simpósio Brasileiro de Exploração Mineral - SIMEXMIN. Ouro Preto, ADIMB, CD-ROM.

Ribeiro-Rodrigues L.C. 1998. Gold in Archean banded iron-formation of the QuadriláteroFerrífero, Minas Gerais, Brazil. The Cuiabá Mine. PhD Thesis, Aachen University, Aachen, 264 p.

Ribeiro Y., Silva R.C.F., Lobato L.M., Lima L.C., Hagemann S.G., Cliff J. 2013. Estudo de inclusões fluidas em veios de quartzo e carbonato ( \pm sulfetos e sulfossais) do depósito Carvoaria Velha, Lineamento Aurífero Córrego do Sítio, Santa Bárbara, Quadrilátero Ferrífero, MG. Geonomos, 21:7-28.

Sandeman H.A., Rafuse H., Copeland D. 2010. The setting of orogenic auriferous quartz veins at the Golden Promise prospect, central Newfoundland, and observations on veining and wall-rock alteration St. John's, Newfoundland Department of Natural Resources, Geological Survey, 16 p. 
Schorscher H.D., Carbonari F.S., Polonia J.C., Moreira J.M.P. 1982 Quadrilatero Ferrífero - Minas Gerais State: Rio das Velhas Greenstone Belt and Proterozoic Rocks. In: International Symposium on Archean and Early Proterozoic Crustal Evolution and Metallogenesis. Salvador, 46 p.

Sequetto-Pereira M.A., Lobato L.M., Rosière C.A., Silva R.C.F. 2013. Classificação dos veios quartzo-carbonáticos de depósitos auríferos no Lineamento Córrego do Sítio, QF, MG. Geonomos, 21:53-71.

Simon G., Kesler S.E., Chryssoulis S. 1999. Geochemistry and textures of gold-bearing Arsenian pyrite, Twin Creeks, Nevada: implications for deposition of gold in Carlin-type deposits. Economic Geology, 94:405-422.
Ye Z. Kesler S.E., Essene E.J., Zohar P.B., Borhauer J.L. 2001. Relation of Carlin-type gold mineralization to lithology, structure and alteration: Screamer zone, Betze-Post deposit, Nevada. Mineralium Deposita, 38:22-38.

Zucchetti M. \& Baltazar O.F. 2000. Rio das Velhas Greenstone Belt lithofacies associations, Quadrilátero Ferrífero, Minas Gerais, Brazil. In: $31^{\text {th }}$ International Geological Congress, Rio de Janeiro. CD-ROM.

Arquivo digital disponível on-line no site www.sbgeo.org.br 